\title{
Study on the Present Situation of Football Teaching in Sports Humanistic Sociology in China
}

\author{
Guoqing Liu \\ Qilu Normal University (China Shandong250200)
}

Keywords: Sports humanities; Football curriculum; Teaching research

\begin{abstract}
In our country, the football curriculum occupies the position of the basic discipline in sports humanities sociology teaching, as the key link of the teaching reform, the football course teaching is related to the whole physical education that can be deepened. This article embarks from the sports humanities sociology soccer curriculum, proposing the teaching present situation to have the reality question, and then proposing a series of solutions to provide the reference for our country soccer teaching improvement.

Our country has a strong practical significance of the study of the humanities and social sports about football courses teaching, one can provide a realistic basis for the cultivation of football talents, and on the other hand, the current social environment strengthen the research on composite football teaching, and promoting the teaching of football can adapt to each other and the external social development the environment. The football course of sport humanistic sociology in China in the field of teaching still needs to be improved mainly for the whole teaching level lags behind which is matched with the law of the development of instructional design not with football, and it severely restricts the sustainable development of teaching humanistic sports sociology in football.
\end{abstract}

\section{Part One the Teaching Situation of Football Teaching in Sports Humanistic Sociology}

The football teaching is called as special project in college physical education, it becomes more and more recognized by the society and enjoy popular entertainment, and football teaching is seemed as a specific form of sports humanities and sociology, the effectiveness of teaching for students' daily life plays a great influence. The inherent characteristics of sports and recreational fitness of football make it have a wide range of social basis in the campus to explore the status of football teaching which has become the focus of social attention.

\section{Design of Football Curriculum}

As far as the current sports humanities sociology curriculum in China, most of the college football professional design can be divided into two categories: social football and professional football education. The time course of football curriculum syllabus does not make specific provisions, so the two categories in the teaching hours has no difference, and it is for football majors after employment cannot produce favorable. Engaged in professional football students who tend to engage in a football coach, and the existing teaching design for the curriculum teaching time which is not complete greatly limits the rational allocation of professional football talents and social demand. Short professional football class can only establish a conceptual understanding of students for professional football, but it could not improve the application level of students in football skills and professional knowledge structure and comprehensive ability fundamentally. So teachers should vigorously improve the students for football, and it will increase the number of professional teaching courses according to the society for professional football talent demand adjustment of football curriculum arrangement while ensuring the teaching of football curriculum, and teaching football has the choice of special arrangements that lay a solid foundation for the effective strengthening students' football professional skills.

\section{The Development of Football Teaching}

Football teaching is mainly aimed at the establishment of the subject teaching syllabus, content and direction as the guidance to carry out the aims of football teaching, curriculum arrangement, teaching in football plan and so on. Accordingly, it increases obstacles to the cultivation of football professional talents which seriously affecting the improvement of football teaching for students of 
professional level and restrict the students practical ability. In the teaching process, the lack of differences in football course content will lead to the basic teaching theory, and the football teaching syllabus from the actual teaching causes the teaching process deviated from the target that do not conducive to teaching content. In view of the special characteristics of football teaching, teaching content existing solely focuses on theoretical knowledge ignoring the essence of practice skills and tactics, and the instructor explains the characteristics of football that focus on teaching and curriculum reform that can not fully meet the needs of the community, and the lack of curriculum practice content leads to professional football students just stay in the level of cognition the content of the theory which can not form a specific objective and professional skills.

\section{Part Two Countermeasures of the Reform on Football Curriculum in Sports Humanistic Sociology}

According to the present situation of football course in sports humanistic sociology, in order to achieve the fundamental teaching reform, it must start from the transformation of football teaching ideas, different groups of football in the football practice learners select individualized teaching mode change to sports as the main purpose of the concept, is committed to the teaching goal which can adapt to shape composite comprehensive talents. At the same time, teachers should expand the specific connotation of teaching on the basis of enriching the curriculum, and it have effect on reasonable allocation of teaching resources, curriculum development programs and social needs closely integrated to promote the continuous reform of football education.

\section{Adjusting Teacher Training}

The process of cultivating football talents is in urgent need of the use of physical education teachers as a medium, the level of teachers is directly related to the level of the overall skills of football majors, but also affecting the construction and future development of the football industry. Thus, in the course of football sports humanistic and social teaching, it should be focused on professional teacher training through the implementation of a series of training policy to improve the actual effect of football teachers teaching organization, football experience and other social groups through the development of communication. Relevant government departments should also provide training construction conditions for football teaching teachers which hold regular football training organizations, football and other forms of dissemination of advanced teaching concept in the teaching system of football course to speed up the football exchanges between universities and the society to promote the teachers as soon as possible, and it can transfer to the student body. Football should broaden the professional quality of teachers, to improve their teaching ability through learning and daily communication industry by taking the way of football coach regularly invited with guest lectures, tactical guidance and so on at the scene to guide the teaching form and to promote the high practical utility of football course. In addition, the teachers should also invite the professionals to visit the teaching scene to guide the content of the teaching with improving the teaching of football antagonistic tactical training. To use the network platform for the exchange of information form of football course in a comprehensive introduction to the basics of football teaching at the same time can improve the professional football for football course learning enthusiasm and encourage the development of university football competition through teaching exchange to find football course education, the government should focus on improving the football teaching innovation mechanism for teaching communication using the football competition, so that students can get strong football teaching based on accurate and in-depth study on the theory of football to promote the enthusiasm of football teaching improvement, so as to improve the teaching effect of the entire football team. In the balance school football teaching level gap at the same time, according to the different forms of the football game level of teaching level, game design science can ensure that the football game will achieve fairness and justice encouraging schools to participate in a football match the enthusiasm in the game to help develop their teaching of football Curriculum schools to improve the teaching level of football with the help of the course, and the participants with the opportunity can achieve their complementary advantages, and this way can ultimately promote the overall level of football teaching improvement. 


\section{Change the Teaching Form}

In the humanistic and social science of physical education in China development in the external environment, the essence of football teaching is through a variety of initiatives to create open football training environment for students, and professional football for the teaching requirements needed for teachers with increased professional skills and practical ability of the football which means football curriculum operation should earnestly improve the old teaching the form of inherent, namely the traditional subject teaching in teaching and demonstration of the error correction teaching with modern football teaching. That is the requirements of football courses that can cover the football competition, daily training, guest experience exchange and skill correction can be a number of links. In the course of teaching add into the content rich and diverse curriculum design, it can greatly extended football course teaching scope to promote students' enthusiasm to participate in the football teaching model at the same time focusing on the development of students for independent research ability of modern football. The implementation of a series of practice based on football training, it means through the development of campus football practice daily school in theory teaching content, autonomy to develop teaching, students will participate in football teaching design and content adjustment programs, and in the teaching practice, college students will participate in the promotion of emphasizing the modern football teaching which will need knowledge applied to practice to improve the employment ability. The football industry should strengthen education theme for football curriculum evaluation system, with teaching assessment system of football curriculum construction in all aspects, understanding the education in the learning process for football education master makes rectification suggestions for the next set of soccer course teachers which will help teachers quickly find the shortcomings in the course of football teaching process hidden. And it helps to make timely adjustments and changes, and ultimately improve the overall quality of China's football teaching.

\section{Update the System Construction}

In the humanistic and social science of physical education in China in the field of football course teaching, it is always adhering to the social needs of the football industry as the starting point, and it needs updating the teaching of football system construction, making efforts to improve the teaching of courses about football. To help students understand the knowledge of modern football at the same time, creating conditions for construction is helpful for students to apply the theory to the future development of football occupation planning, which improve the use of football curriculum knowledge and skills learned to solve modern football teaching sustainable progress possible problems in improving the ability of individual guidance the practice of students' application of football course fundamentally. To achieve what effect, the theory applied to the actual teaching can improve the overall quality of football industry. In the development of the teaching plan, the teachers should pay more attention to the scientific and reasonable choice of teaching resources, and expand the content from the content of football teaching. Colleges and universities should be combined with the situation and future development of personalized construction, re-arrange football teaching arrangements and make efforts to develop in line with the actual characteristics of the school football education system. The difference between target and talent cultivation of the ideological teaching courses for soccer schools based on the actual teaching plan of football course in the future development of the football industry should actively cooperate with the planning of sports talents in universities curriculum system, to provide reference for the enhancement of football talent practice ability, and it can meet the high quality talented football professional society about the required talents to do the basic work. The teachers should speed up the implementation of the integration of football teaching and the new teaching model, and carry out the reform in the teaching of sports humanities and sociology. To enhance the ability of football players to adapt to the external environment and improve the ability of daily curriculum innovation, the football teachers should enrich the scientific and creative talents for the sports industry.

With the rapid development of sport humanistic sociology in China, football is widely popular in daily life, and along with the increasing rise of football and football industry, industry design teaching of football curriculum by education and sports circles get attention. This article embarks 
from the current sports humanistic sociology in our country soccer curriculum teaching question, looking at the soccer education development process, it proposes the ways to be able to enhance the soccer talented person comprehensive ability a series of suggestions which include the scientific and reasonable football curriculum design, knowledge theory and practice training coordination, curriculum learning and teaching ability of the overall arrangement to improve football practitioners using scientific guidance of utility theory related to football fitness, and it can finally promote the theory of football industry with training a number of comprehensive high quality professional football talents for the modern society.

\section{References}

[1] Xuetian Ma, Yi Li.Theory and practice of football match[M].Beijing: Beijing Sport University Press,2008.31-32.

[2] Chongxi Wang.Football teaching design[M].Beijing: Higher Education Press, 2009.

[3] Chongxi Wang.Ball game-Football[M].Beijing: Higher Education Press,2005. 